\title{
THE EFFECT OF PARTIAL REMOVAL OF THE CORPORA LUTEA ON THE OVARIAN CYCLE IN THE RAT
}

\author{
E. B. SMALSTIG, D. R. BENNETT AND R. L. COCHRANE \\ Lilly Research Laboratories, Eli Lilly and Company, Indianapolis, Indiana 46206, U.S.A.
}

(Received 24th Fuly 1972)

Studies on compounds that inhibit luteal progesterone synthesis and/or secretion in the rat (Mason, Tinsley \& Cochrane, 1969; Tinsley, Rathmacher \& Cochrane, 1970) have led to the development of a cursory screen for such activity which uses the induction of an oestrous or pro-oestrous vaginal smear in the pseudopregnant rat as an end-point. A number of reports (McKeown \& Zuckerman, 1937; Rothchild, 1960; Zeilmaker, 1965; Smalstig, Bennett, Shaar \& Cochrane, 1971) have indicated that this is probably justified since complete removal of the CL of pseudopregnant rats will cause the appearance of an oestrous, or pro-oestrous, vaginal smear within 2 to 7 days.

The present study was undertaken to equate the degree of luteal suppression necessary for the expression of oestrous or pro-oestrous vaginal smears in pseudopregnant rats with the maximum number of CL that will allow this expression. As in the previous study on complete removal of CL (Smalstig et al., 1971), this study on partial excision also encompassed the effects of the operational procedures on 'delayed pseudopregnancy' (Everett, 1967).

The experimental animals were virgin female Carworth CFE-strain rats, weighing 231 to $308 \mathrm{~g}$, maintained and housed in a similar manner to that described previously (Smalstig et al., 1971). Daily vaginal smears were taken in the morning for at least 12 days preceding, and then throughout, the experimental period. The smears were taken by lavage with distilled water and were examined unstained and fresh. All test animals completed at least three normal 4- to 5-day oestrous cycles immediately before being included in the experiment.

Pseudopregnancy was induced by the same method as that described by Smalstig et al. (1971), and at the same time (Day 0) in the cycle. The CL removal was accomplished by temporarily clamping the ovarian blood vessels with one or two 45-mm artery forceps, splitting the ovarian bursa and with the aid of watchmaker's forceps and Beebe loupes $(2 \cdot 5 \times)$, removing all of the CL, except those that were to remain in the animal. Sham-removal of CL consisted of clamping the ovarian blood vessels and splitting the ovarian bursa. In the case of the partial removals, the CL that were left intact were always those judged to be the most recent by their size, redness and, where possible, the presence of red stigmata. Some CL, however, may have originated from cycles earlier than the cycle of the operation. Equal numbers of CL were left in each 
ovary, except where odd numbers were involved, when the extra CL was left in alternate ovaries.

Cycle length and duration of pseudopregnancy were determined by the number of days elapsing between the last day of a vaginal smear of predominantly cornified epithelial cells and the day of a succeeding vaginal smear of predominantly cornified, or nucleated, epithelial cells, which was followed by a predominantly leucocytic smear. As in the previous study (Smalstig et al., 1971), cycles of a duration of 7 to 21 days were considered to be cycles of pseudopregnancy and were classified as 'long', and cycles of a duration of 6 days, or

Table 1. The effect of the number of remaining CL on the ovarian cycle in pseudopregnant rats following partial CL removal

\begin{tabular}{|c|c|c|c|c|c|c|c|}
\hline \multirow{3}{*}{$\begin{array}{l}\text { No. of } C L \\
\text { remaining }\end{array}$} & \multirow{3}{*}{$\begin{array}{l}\text { Total } \\
\text { no. of } \\
\text { rats in } \\
\text { group }\end{array}$} & \multicolumn{2}{|c|}{ First cycle } & \multirow{2}{*}{\multicolumn{4}{|c|}{$\begin{array}{c}\text { Sequences of the lengths of the second } \\
\text { and third cycles** (no. of rats exhibiting } \\
\text { each) }\end{array}$}} \\
\hline & & \multirow{2}{*}{$\begin{array}{l}\text { No. of } \\
\text { rats }\end{array}$} & \multirow{2}{*}{$\begin{array}{l}\text { Cycle } \\
\text { length } \\
\text { (days) }\end{array}$} & & & & \\
\hline & & & & Short-short & Short-long & Long-short & Long-long \\
\hline 0 & 5 & $\begin{array}{l}4 \\
1\end{array}$ & $\begin{array}{l}4 \text { to } 6 \\
21\end{array}$ & $\begin{array}{l}0 \\
\mathrm{I}\end{array}$ & $\begin{array}{l}0 \\
0\end{array}$ & $\begin{array}{l}4 \\
0\end{array}$ & $\begin{array}{l}0 \\
0\end{array}$ \\
\hline 1 & 8 & $\begin{array}{l}5 \\
3\end{array}$ & $\begin{array}{l}4 \text { to } 5 \\
14 \text { to } 20\end{array}$ & $\begin{array}{l}0 \\
3\end{array}$ & $\begin{array}{l}3 \\
0\end{array}$ & $\begin{array}{l}2 \\
0\end{array}$ & $\begin{array}{l}0 \\
0\end{array}$ \\
\hline 2 & 8 & $\begin{array}{l}6 \\
2\end{array}$ & $\begin{array}{l}4 \text { to } 5 \\
11 \text { to } 15\end{array}$ & $\begin{array}{l}1 \\
1\end{array}$ & $\begin{array}{l}1 \\
0\end{array}$ & $\begin{array}{l}2 \\
1\end{array}$ & $\begin{array}{l}2 \\
0\end{array}$ \\
\hline 3 & 8 & $\begin{array}{l}4 \\
4\end{array}$ & $\begin{array}{l}4 \text { to } 5 \\
7 \text { to } 16\end{array}$ & $\begin{array}{l}0 \\
2\end{array}$ & $\begin{array}{l}0 \\
0\end{array}$ & $\begin{array}{l}2 \\
2\end{array}$ & $\begin{array}{l}2 \dagger \\
0\end{array}$ \\
\hline 4 & 9 & $\begin{array}{l}7 \\
2\end{array}$ & $\begin{array}{c}4 \text { to } 5 \\
13\end{array}$ & $\begin{array}{l}0 \\
2\end{array}$ & $\begin{array}{l}1 \\
0\end{array}$ & $\begin{array}{l}5 \\
0\end{array}$ & $\begin{array}{l}1 \\
0\end{array}$ \\
\hline 6 & 6 & 4 & $\begin{array}{l}4 \text { to } 5 \\
14 \text { to } 16\end{array}$ & 1 & $\begin{array}{l}2 \\
0\end{array}$ & $\begin{array}{l}1 \\
0\end{array}$ & $\begin{array}{l}0 \\
0\end{array}$ \\
\hline 10 & 8 & $\begin{array}{l}3 \\
5\end{array}$ & $11^{4}$ to 21 & $\begin{array}{l}0 \\
2 \ddagger\end{array}$ & $\begin{array}{l}0 \\
0 \ddagger\end{array}$ & $\begin{array}{l}2 \\
2\end{array}$ & $\begin{array}{l}1 \\
0\end{array}$ \\
\hline 14 & 8 & $\frac{1}{6 \Omega}$ & $\begin{array}{l}4 \\
12 \text { to } 165\end{array}$ & $\begin{array}{l}0 \\
4\end{array}$ & $\begin{array}{l}0 \\
0\end{array}$ & $\begin{array}{l}1 \\
2\end{array}$ & $\begin{array}{l}0 \\
0\end{array}$ \\
\hline $\begin{array}{l}\text { All } \\
\text { (sham- } \\
\text { operation) }\end{array}$ & 6 & $\begin{array}{l}1 \\
5\end{array}$ & $\begin{array}{c}4 \\
8 \text { to } 16\end{array}$ & $\begin{array}{l}0 \\
3\end{array}$ & $\begin{array}{l}0 \\
0\end{array}$ & $\begin{array}{l}1 \\
2\end{array}$ & $\begin{array}{l}0 \\
0\end{array}$ \\
\hline
\end{tabular}

* Short cycles $=6$ days and less; long cycles $=7$ to 21 days.

† One of these two animals was in oestrus or pro-oestrus for 9 days of its 11-day third cycle. ¥ One animal had a short second cycle but was not allowed to complete a third cycle.

$\$$ The seventh had a first cycle of over 49 days and did not return to oestrous.

less, were classified as 'short'. The cycle of pseudopregnancy during which removal, or sham-removal, of the CL was performed was considered the first cycle (or cycle of the operation), and the following two cycles, the second and third cycles, respectively.

A summary of the results of the experiment appears in Table 1. Each group of rats, based on the number of CL remaining, has been divided into two subgroups (lines) according to the duration of the first cycle. The first line consists of the animals that failed to become pseudopregnant, or that responded to the operation by returning to oestrous, or pro-oestrous (as judged by the vaginal 
smear), in 3 to 5 days. The second line consists of the animals that remained pseudopregnant.

It can be seen that complete removal of the CL resulted in $80 \%$ of the animals exhibiting an oestrous or pro-oestrous vaginal smear within 3 to 5 days of operation, while the majority $(83 \%)$ of the animals subjected to sham-operation remained pseudopregnant and failed to exhibit an oestrous or pro-oestrous vaginal smear until 7 to 15 days after the operation. This corroborates the earlier work of Smalstig et al. (1971).

The results from the animals subjected to partial removal of the CL were not clear-cut and it seems possible that the number of CL formed at ovulation had some bearing on the functional capabilities of those remaining in the ovaries after partial excision. No allowance was made for this aspect of the problem in the present study. In addition, the mechanical removal of rat $C L$ is at best a fairly crude procedure. In spite of all of these shortcomings, 50 to $78 \%$ of the animals with six CL, or less, left in their ovaries exhibited oestrous or prooestrous vaginal smears within 3 to 5 days of the operation. If ten or more CL remained in the ovaries, however, the majority (62 to $86 \%$ ) of the animals failed to exhibit an oestrous or pro-oestrous vaginal smear until 10 to 20 days after the operation. This indicates that approximately seven to ten CL are required to maintain pseudopregnancy with consistency in the rat.

The present results compare with reports in the literature that unilateral ovariectomy will terminate a reserpine-induced pseudopregnancy in the rat (Chatterjee \& Harper, 1970) but will rarely terminate pregnancy or cause the appearance of oestrous or pro-oestrous vaginal smears in pregnant rats (Kraicer \& Shelesnyak, 1968; Kraicer, 1969). Three CL have been reported to inhibit the appearance of oestrous vaginal smears in about $50 \%$ of the cases in unilaterally ovariectomized pregnant rats and to maintain pregnancy from Day 5 to term in $100 \%$ of the cases in the same type of animal (Kraicer, 1969). Kelsey \& Meyer (1950) found that only two CL were necessary to maintain pregnancy from Day 8 to term in the rat possessing both ovaries.

Several studies have shown that oestrous and/or pro-oestrous vaginal smears need not be accompanied by ovulation (Kraicer \& Shelesnyak, 1964; Schwartz, 1969). It is quite probable that fewer CL are required to inhibit ovulation than to suppress the occurrence of an oestrous or pro-oestrous vaginal smear. No attempt was made to determine whether ovulation had occurred in the present study, however, since the scope of the study was only to relate the degree of luteal suppression to the expression of an oestrous or pro-oestrous vaginal smear as might occur in our cursory screen for luteal inhibitors.

The effects of partial CL removal on the incidence of 'delayed pseudopregnancy' (a 'long' cycle in the second and/or third cycle) seemed to be little different from those of complete removal. Most $(94 \%)$ of the animals that exhibited an oestrous or pro-oestrous vaginal smear within 3 to 5 days after operation also displayed 'delayed pseudopregnancy', no matter how many CL were left in the ovary. Conversely, a majority $(69 \%)$ of the animals that remained pseudopregnant in the first cycle failed to exhibit 'delayed pseudopregnancy'. Thus, it appears that the number of CL left in the ovaries of the animals during the first cycle influenced the incidence of 'delayed pseudopregnancy' 
only by an effect on the incidence of animals remaining pseudopregnant during the first cycle. These results add little information to that already reported in the literature on 'delayed pseudopregnancy' (Kraicer \& Shelesnyak, 1964; 1968; Zeilmaker, 1965; Everett, 1967; Kisch, 1968; Smalstig et al., 1971) and are consistent with the explanations of this phenomenon hypothesized by Zeilmaker (1965) and also appearing in the report of Smalstig et al. (1971).

We would like to thank Dr D. M. Brennan, Dr R. J. Kraay and Dr M. X. Zarrow for their help and advice in preparation of the manuscript.

\section{REFERENCES}

Ghatterjee, A. \& Harper, M. J. K. (1970) Interruption of pseudopregnancy in rats by hemiovariectomy. Endocrinology, 87, 173.

Everetr, J. W. (1967) Provoked ovulation or long-delayed pseudopregnancy from coital stimuli in barbiturate-blocked rats. Endocrinology, 80, 145.

Kelsey, R. C. \& Meyer, R. K. (1950) Amount of luteal tissue required for the maintenance of pregnancy in the rat. Proc. Soc. exp. Biol. Med. 75, 736.

$\mathrm{K}_{\mathrm{ISCH}}$, E. S. (1968) The incidence of pseudopregnancy after ergocornine-induced interruption of the luteal phase in the rat. 7. Reprod. Fert. 17, 221.

KRAicer, P. F. (1969) Studies on the effect of nidation. XXXV. Effect of removal of corpora lutea on ovo-implantation and pregnancy in the rat. 7 . Reprod. Fert. 18, 75.

Kraicer, P. F. \& Shelesnyak, M. C. (1964) Studies on the mechanism of nidation. IX. Analysis of the responses to ergocornine-an inhibitor of nidation. J. Reprod. Fert. 8, 225.

Kraicer, P. F. \& ShelesnyaK, M. C. (1968) Interruption of pregnancy, induction of ovulation and delayed pseudopregnancy following suppression of luteal function. Acta endocr., Copenh. 58, 251.

Mason, N. R., Tinsley, F. C. \& Cochrane, R. L. (1969) Effect of prolactin and 5-bromo-2-thienylethyl ketone thiosemicarbazone on ovarian progestin levels in the rat. Endocrinology, 85, 831.

McKeown, T. \& Zuckerman, S. (1937) The suppression of oestrus in the rat during pregnancy and lactation. Proc. R. Soc., B, 124, 464.

RотнсншD, I. (1960) The corpus luteum-pituitary relationship: the association between the cause of luteotrophin secretion and the cause of follicular quiescence during lactation; the basis for a tentative theory of the corpus luteum-pituitary relationship in the rat. Endocrinology, 67, 9.

Schwartz, N. B. (1969) A model for the regulation of ovulation in the rat. Recent Progr. Horm. Res. 25,1 .

Smalstig, E. B., Bennett, D. R., ShaAR, C. J. \& Cochrane, R. L. (1971) Effects of corpus luteum removal on ovarian cyclicity of the rat. Endocrinology, 89, 714.

Tinsley, F. G., Rathmacher, R. P. \& Cochrane, R. L. (1970) The effect of 5-bromo-2-thienyl-ethyl ketone thiosemicarbazone on the induced deciduomal response in the rat. $\mathcal{J}$. Reprod. Fert. 21, 233.

Zeilmaker, G. H. (1965) Normal and delayed pseudopregnancy in the rat. Acta endocr., Copenh. $49,558$. 